\title{
The COVID-19 pandemic and the public health challenges in Bangladesh: a commentary
}

\author{
Amlan Haque \\ School of Business, CQUniversity, Sydney Campus, Sydney, Australia
}

\begin{abstract}
Purpose - The purpose of this paper is to highlight the current pandemic situation of coronavirus disease 2019 (COVID-19) in Bangladesh, how the Government is managing this unprecedented condition and encountering these increasing public health challenges.

Design/methodology/approach - This paper is a viewpoint of the current COVID-19 pandemic situation in Bangladesh.

Findings - As one of the most densely populated countries, Bangladesh is vulnerable to COVID-19. Currently, the infection of COVID-19 is spreading fast and started to capture all the parts of Bangladesh. The Government of Bangladesh has already taken several preventive measures to overcome the pandemic such as declaring hotspots of COVID-19 and setting lockdowns, increasing mass awareness through social media and satellite TV channels. They are also encouraging private and community healthcare initiatives to increase hospital beds and COVID-19 treatment facilities. Besides, the Government has deployed defence force and additional health workers and increased public holidays to reduce the number of coronavirus infections. However, both the number of infected people and the death toll is rising, and there are growing challenges that the Government and public healthcare professions need to overcome.

Originality/value - This paper delivers information about the present developing situation of COVID-19 in Bangladesh, how the Government is handling and public health challenges that have raised. This paper can be helpful for the policymakers and Government officials for effective public health interventions.
\end{abstract}

Keywords COVID-19, Pandemic, Public health challenges, Bangladesh

Paper type Commentary

\section{Introduction}

The novel coronavirus 2019 (COVID-19) is a communicable disease that has not been previously identified in humans. The World Health Organization (WHO) announced COVID19 as a pandemic on March 11, 2020. The unprecedented crisis of COVID-19 has posed an enormous challenge to the healthcare sector, particularly in developing countries such as Bangladesh.

\section{Global condition}

COVID-19 was identified in Wuhan, China, in December 2019. Within a month, the pandemic had a negative impact on global economies and societies worldwide [1,2]. Public healthcare is suffering an unprecedented challenge due to the COVID-19 pandemic on a global scale. The WHO advised Southeast Asia to take prompt and suitable public health initiatives to control the increased transmission rate and pandemic situation. However, in the last two months, both the infection rate and death rate from COVID-19 have been escalating in the South Asian region, particularly in India, Pakistan and Bangladesh [3].

(C) Amlan Haque. Published in Journal of Health Research. Published by Emerald Publishing Limited. This article is published under the Creative Commons Attribution (CC BY 4.0) license. Anyone may reproduce, distribute, translate and create derivative works of this article (for both commercial and noncommercial purposes), subject to full attribution to the original publication and authors. The full terms of this license may be seen at http://creativecommons.org/licences/by/4.0/legalcode
COVID-19 pandemic in Bangladesh

Received 14 July 2020 Revised 26 July 2020 Accepted 7 August 2020 
JHR

34,6

\section{The scenario in Bangladesh}

India has the highest number of COVID-19 cases in the South Asian region and because it shares a 4,100 kilometer (2,500 miles) international border with Bangladesh [4], the COVID-19 rate has spread across these borders at its highest among the South Asian countries [3]. As of July 7, 2020 (2: 34 pm), Bangladesh confirmed 168,645 infected cases of COVID-19, a death toll of 2,151, a cure rate of 78,102 and a total of 876,480 testings [5].

After the early detection of COVID-19 in Wuhan, the Bangladeshi Government commenced testing travelers from China from January 22, 2020 at the Hazrat Shahjalal International Airport in Dhaka [6, 7]. However, the first three coronavirus cases in Bangladesh were traced back to Italy on March 8, 2020 [8]. On March 18, 2020, Bangladesh reported its first COVID-19 death of a person aged over 70 years who had other morbidities [9]. On 14 March, the Government of Bangladesh decided to suspend on-arrival visas for all [10]. Furthermore, the Government closed all schools and universities from March 17, 2020 [11]. The Government declared a nationwide 10-day holiday for all public and private offices from March 26 to April 4, 2020 except the emergency services [12]. People were requested to remain at home to practice social distancing unless in an emergency, and public transport became limited [12]. In addition to the police and the Rapid Action Battalion (RAB), the Government deployed the Army to safeguard social distancing [10]. Also, on April 9, 2020, the Government imposed a "complete lockdown" on the well-known tourist destination, Cox's Bazar, which is also vulnerable because of the Rohingya refugees $[13,14]$.

At the individual level, the information communication technology (ICT) division of the Government of Bangladesh and the Directorate General of Health Services (DGHS) launched a smart mobile phone application (Corona Tracer BD) that provides the latest research-based information regarding COVID-19, indicates nearby health and testing facilities, the latest statistics on the pandemic and Government announcements [5]. Besides, several web-based portals such as the Governmental portal (https://corona.gov.bd/) or Institute of Epidemiology, Disease Control and Research (IEDCR) portal (https://www.iedcr.gov.bd/) provide daily updates about the COVID-19 situation in Bangladesh. As of July 8, 2020, according to IEDCR (2.30 p.m.), more than $50 \%$ of infected COVID-19 patients were aged between 21 to 40 years and $65 \%$ or more deaths were reported in the over 50 age category with males constituting more than $70 \%$ of the infected and death rates [9]. As of July 7, 2020, the Government of Bangladesh set up a public health emergency control room at IEDCR and established 629 institutes all over the country (e.g. 64 districts) to provide immediate COVID-19-related services including quarantine facilities for 31,991 persons [5]. At present (on July 7, 2020), the Bangladeshi Government reported a total of 14,775 hospital beds and 401 Intensive Care Unit (ICU) beds [5]. On 7 July, IEDCR reported the availability of 11,520 oxygen cylinders, including 224 hi-flow nasal cannulas (HFNC) in Bangladesh [9].

\section{Public health challenges in Bangladesh during the COVID-19 pandemic}

With a population of 162 million, Bangladesh ranks as the eighth-most populous country in the world $[3,15]$. The healthcare system of Bangladesh is mostly unregulated and comprises four cohorts including Government, private sector, non-Governmental organizations or NGOs and international development organizations [16].

This paper highlights the socioeconomic and critical challenges faced by Bangladesh during the COVID-19 pandemic. First, Bangladesh has a severe scarcity of COVID-19 testing kits. The Government of Bangladesh has about 100 thousand testing kits in stock, and near around 20 thousand have been distributed to different testing facilities around the country [17]. However, some experts have questioned the efficiency of the available testing kits because of their high rate of false-negative results [18]. Moreover, at the beginning of the COVID-19 pandemic in Bangladesh, the IEDCR managed to test 11,223 people, but this 
constitutes approximately 68 tests per million population $[19,20]$. Consequently, this puts Bangladesh among the lower-ranked countries for COVID-19 testing rates in the world. Because of these criticisms, the Bangladeshi Government expanded its testing numbers [21] and as of July 7, 2020, the total number of testing centers has increased to 74 [5].

Second, the Government of Bangladesh struggles to manage the population of the capital city, Dhaka, where more than 46 thousand people live per square kilometer [22]. Moreover, Dhaka has about 1.1 million slum dwellers making it impossible to practice effective social distancing [17,22]. Consequently, effective enforcement of social distancing is an impossible task for the law and enforcement departments in Bangladesh.

Third, the healthcare situation in Bangladesh is worsening because of the increasing number of COVID-19 infected patients. Because of increasing patient numbers, community clinics and hospitals are becoming a source of COVID-19 transmission. At present, the most challenging issue is to ensure ICU and ventilator support in the community or rural clinics and the supply of oxygen-cylinders to hospitals [23]. Therefore, the increasing number of COVID-19 cases and the sudden high demand for oxygen-cylinders have put enormous pressure on the healthcare system. The need to ensure adequate supply from local manufacturers or the need to import from other countries is urgently needed.

Fourth, the lack of coordination among the policymakers, healthcare professionals and law enforcement departments has been heavily criticized. Scholars and researchers have emphasized the need for instant, supportive collaboration among the central and local Government authorities including the healthcare workforce, along three other sectors (e.g. private, NGOs and the foreign aid organizations) to minimize the impact of the COVID-19 pandemic in Bangladesh.

Fifth, the recent incidence of false and illegal certification about COVID-19 reports have become a new crisis for this pandemic situation in Bangladesh. Some Dhaka-based private hospitals and criminal syndicates are selling fake coronavirus test certificates to profit from the COVID-19 pandemic [24, 25].

Finally, some socioeconomic challenges are noteworthy such as the incorrect perception and rumors about COVID-19 [17, 26, 27], lack of proper health education [26], digital interventions and lack of IT literacy [28], the uncertainty of long-time lockdown [27], the Rohingya refugee crisis [14], unemployment rates [17, 26] and suicides [24].

\section{Conclusion}

Despite the Governmental initiatives in place, much more could have been done much earlier with short, medium and long-term strategic plans put in effect. COVID-19 has taught every nation, including Bangladesh a lesson regarding the importance of effective healthcare planning and preparations to deal with any future pandemic. Social distancing is a deterrent, but lockdowns can be detrimental to the national economy. Effective coordination among the Government policymakers and the local healthcare workforce is necessary to ensure emergency health services can deal with the pandemic more effectively.

\section{References}

1. MacIntyre CR. On a knife's edge of a COVID-19 pandemic: is containment still possible?. Public Health Res Pract. 2020; 30(1): 3012000. doi: 10.17061/phrp3012000.

2. Shigemura J, Ursano RJ, Morganstein JC, Kurosawa M, Benedek DM. Public responses to the novel 2019 coronavirus (2019-nCoV) in Japan: mental health consequences and target populations. Psychiatry Clin Neurosci. 2020 Apr; 74(4): 281-2. doi: 10.1111/pcn.12988.

3. World Health Organization [WHO]. Coronavirus disease (COVID-19): Situation report - 168. [updated 2020 July 6; cited 2020 July 12]. Available at: https://www.who.int/docs/default-source/ coronaviruse/situation-reports/20200706-covid-19-sitrep-168.pdf?sfvrsn=7fed5c0b_2. 
JHR 34,6

4. Why India and Bangladesh have the world's craziest border. [updated 2015 Junuary 25; cited 2020 July 14]. Available at: https://www.economist.com/the-economist-explains/2015/06/24/why-indiaand-bangladesh-have-the-worlds-craziest-border.

5. COVID19-Corona.gov.bd. Coronavirus disease 2019 (COVID-19): Information Bangladesh. [cited 2020 July 14]. Available at: https://corona.gov.bd/.

6. ABC News. Virus prompts temperature checks, extra cleaning at airports. [updated 2020 January 22; cited 2020 July 10]. Available at: https://abcnews.go.com/Health/wireStory/countries-join-chinaresponding-coronavirus-68424857.

7. Screening starts at Dhaka, Ctg airports. [updated 2020 January 22; cited 2020 July 14]. Available at: http://www.theindependentbd.com/post/233343.

8. Paul R. Bangladesh confirms its first three cases of coronavirus. [updated 2020 March 8; cited 2020 July 14]. Available at: https://www.reuters.com/article/us-health-coronavirus-bangladeshidUSKBN20V0FS.

9. Institute of Epidemiology Disease Control and Research [IEDCR]. [cited 2020 July 14]. Available at: https://www.iedcr.gov.bd/.

10. Army to enforce social distancing. [updated 2020 March 23; cited 2020 July 12]. Available at: https://tbsnews.net/bangladesh/bangladesh-deploys-army-enforce-social-distancing-overcorona-60052.

11. Educational institutions to remain closed till March 31. [updated 2020 March 16; cited 2020 July 13]. Available at: https:/tbsnews.net/bangladesh/education/govt-orders-closure-all-educational-institutions-march17-56947?fbclid=IwAR1G_KZ3PRJlmQH15mSoUnO91S7OV5WP6HuXYLhfXelJMm0pma0Yo0WQDqQ.

12. Coronavirus outbreak. Govt orders closure of public, private offices from March 26 to April 4. [updated 2020 March 23; cited 2020 July 11]. Available at: https:/www.thedailystar.net/coronavirusdeadly-new-threat/news/govt-offices-closed-march-26-april-4-cabinet-secretary-1884730.

13. Coronavirus. Rohingya camps in Bangladesh put under 'complete lockdown'. [updated 2020 April 9; cited 2020 July 14]. Available at: https://www.straitstimes.com/asia/south-asia/coronavirusrohingya-camps-in-bangladesh-put-under-complete-lockdown.

14. Islam MN, Inan TT, Islam A. COVID-19 and the Rohingya refugees in Bangladesh: the challenges and recommendations. Asia Pac J Public Health. 2020 Jun; 32(5): 283-284. doi: 10.1177/ 1010539520932707.

15. World Health Organization [WHO]. Coronavirus. [cited 2020 July 11]. Available at: https://www. who.int/health-topics/coronavirus\#tab=tab_1.

16. Islam A, Biswas T. Health system in Bangladesh: challenges and opportunities. Am J Health Res. 2014; 2(6): 366-74. doi: 10.11648/j.ajhr.20140206.18.

17. Anwar S, Nasrullah M, Hosen MJ. COVID-19 and Bangladesh: challenges and how to address them. Frontiers in Pub Health. 2020; 8: 154. doi: 10.3389/fpubh.2020.00154.

18. CBC.Canada refuses to approve rapid coronavirus blood test. [updated 2020 April 9; cited 2020 July 14]. Available at: https://www.cbc.ca/player/play/1722212931886.

19. Mozid A. Novel coronavirus (COVID-19) press release. [cited 2020 July 14]. Available at: https:// www.dghs.gov.bd/index.php/en/home/5373-novel-coronavirus-covid-19-press-release.

20. Worldometer. Coronavirus cases. [cited 2020 July 11]. Available at: https://www.worldometers. info/coronavirus/.

21. World Health Organization [WHO] - Bangladesh. COVID-19: Situation report No. 6. [updated 2020 April 7; cited $2020 \mathrm{Jul} \mathrm{11].} \mathrm{Available} \mathrm{at:} \mathrm{https:/www.who.int/docs/default-source/searo/}$ bangladesh/covid-19-who-bangladesh-situation-reports/who-ban-covid-19-sitrep-06.pdf? sfvrsn=36254da0_6.

22. Bangladesh Bureau of Statistics [BBS]. Census of slum areas and floating population 2014. Dhaka: Ministry of Planning; 2015. [cited 2020 July 10]. Available at: http://203.112.218.65:8008/ WebTestApplication/userfiles/Image/Slum/FloatingPopulation2014.pdf. 
23. The Financial Express. Crisis of oxygen cylinder. [updated 2020 June 12; cited 2020 July 10]. Available at: https://thefinancialexpress.com.bd/editorial/crisis-of-oxygen-cylinder-1591803150.

24. Bangladesh arrests hospital owner over fake coronavirus results. [updated 2020 July 16; cited 2020 July 26]. Available at: https://www.aljazeera.com/news/2020/07/bangladesh-arrests-hospitalowner-fake-coronavirus-results-200716033249660.html.

25. Alam MS, Alam MZ, Nazir KHMNH, Bhuiyan MAB. The emergence of novel coronavirus disease (COVID-19) in Bangladesh: present status, challenges, and future management. J Adv Vet Anim Res. 2020; 7(2): 198-208. doi: 10.5455/javar.2020.g410.

26. Bodrud-Doza M, Shammi M, Bahlman L, Islam ARMT, Rahman MM. Psychosocial and socioeconomic crisis in Bangladesh due to COVID-19 pandemic: a perception-based assessment. Front Public Health. 2020; 8: 341. doi: 10.3389/fpubh.2020.00341.

27. Bhuiyan AKMI, Sakib N, Pakpour AH, Griffiths MD, Mamun MA. COVID-19-related suicides in Bangladesh due to lockdown and economic factors: case study evidence from media reports. Int J Ment Health Addict. 2020: 1-6. doi: 10.1007/s11469-020-00307-y.

28. Islam MN, Islam AKMN. A systematic review of the digital interventions for fighting COVID-19: the Bangladesh perspective. IEEE Access. 2020; 8: 114078-87. doi: 10.1109/ACCESS.2020.3002445.

\section{Corresponding author}

Amlan Haque can be contacted at: ajhaque@gmail.com

For instructions on how to order reprints of this article, please visit our website: 